\title{
Landmarks in the history of adrenal surgery
}

\author{
Marios Papadakis, ${ }^{1,2}$ Andreas Manios, ${ }^{3}$ Georgios Schoretsanitis, ${ }^{3}$ \\ Constantinos Trompoukis ${ }^{2}$
}

\begin{abstract}
${ }^{1}$ Department of Endocrine Surgery, HELIOS Klinikum Wuppertal, University Hospital Witten-Herdecke, Wuppertal, Germany, ${ }^{2}$ Department of History of Medicine, School of Medicine, University of Crete, Heraklion, ${ }^{3}$ Department of Surgical Oncology, University Hospital, Heraklion, Greece
\end{abstract}

Sir,

The last 100 years have seen a revolution in the understanding of adrenal disease and its surgical treatment. The isolation of its hormones, the detailed study of the adrenal medulla and the cortex together with the enormous expansion of surgical methods served as catalysts to this revolution. The Greek word for adrenal (epinephridio, from the Greek epi, upon, and nephros, kidney) dates back to the age of Homer who mentions the adrenal glands. In his Iliad $(21,204)$, when describing Achilles' killing of an adversary, Homer writes: "About him, indeed, the eels and fishes were busied, eating and nibbling the fat around his kidneys." ${ }^{1}$ Although Homer seems to be aware of the tissue upon the kidneys, translated by Buckley as fat, ${ }^{1}$ and because of his extensive anatomical knowledge, he appears here to be referring to the left flank in general. In the Bible, Leviticus (3:4) contains a similar description of the adrenals,

Key words: Adrenalectomy, Adrenal glands, Adrenal surgery, Endocrine surgery, Cushing disease, Pheochromocytoma

Address for correspondence:

Marios Papadakis, Department of History of Medicine, School of Medicine, University of Crete, Voutes Campus, Heraklion, Crete, GR-71003, Greece;

E-mail: mpapadakis@med.uoc.gr

Received 06-07-2015, Accepted 16-07-2015 which again were understood to be integral parts of the kidneys: "the kidneys and the fat that is on them at the loins". ${ }^{2}$

Galen was the first to provide a detailed description of the adrenal veins, defining the adrenal glands as "bodies around the kidneys": "For when the vein first appears outside the liver, before reaching the loin, being still high, at its own right side, it sends to the capsule of the right kidney and the bodies [suprarenals?] around this sometimes spiderwer-like, sometimes hairlike, and sometimes thicker contributions".,34

Bartolomeo Eustachio (or Bartholomeus Eustachius), a famous Italian anatomist who flourished in 16 th century Rome, was the first to recognize the adrenal gland as a distinct anatomical entity. His treatise titled "Opuscula Anatomica" and published in Venice in 1564 contains the first description of the adrenal glands, which he labeled "glandulae quae renibus incumbent" (glands lying on the kidney). ${ }^{5} \mathrm{He}$ defines the adrenals as glands "diligently overlooked by other anatomists", that are capped on the upper kidney surface resembling a kidney in shape but sometimes bigger in size: "Both kidneys are capped on the extremity towards the cava by a gland. Both are connected with a fold of the peritoneum in such a way that one, if he is not very attentive, does really overlook them, as if they were not present. Their shape resembles that of the kidneys...sometimes one is bigger, sometimes another...early anatomists and those who write ample treatises on this art in our days failed to 
detect them ". ${ }^{6,7}$ Assisted by Pier Matteo Pini, an artist relative, Eustachio prepared an excellent series of copperplate engravings of anatomical illustrations. The series included the first depiction of the adrenal glands (Figure 1) and was meant to accompany a medical treatise, left however uncompleted when Eustachio died in 1574. The engravings passed through Pini and his heirs into the Vatican Library's possession where they remained unprinted until discovered by Giovanni Maria Lancisi at the beginning of the 18th century. Lancisi, personal physician to Pope Clement XI, published the entire series of 47 splendid plates under the title: "Tabulae Anatomicae Bartholomei

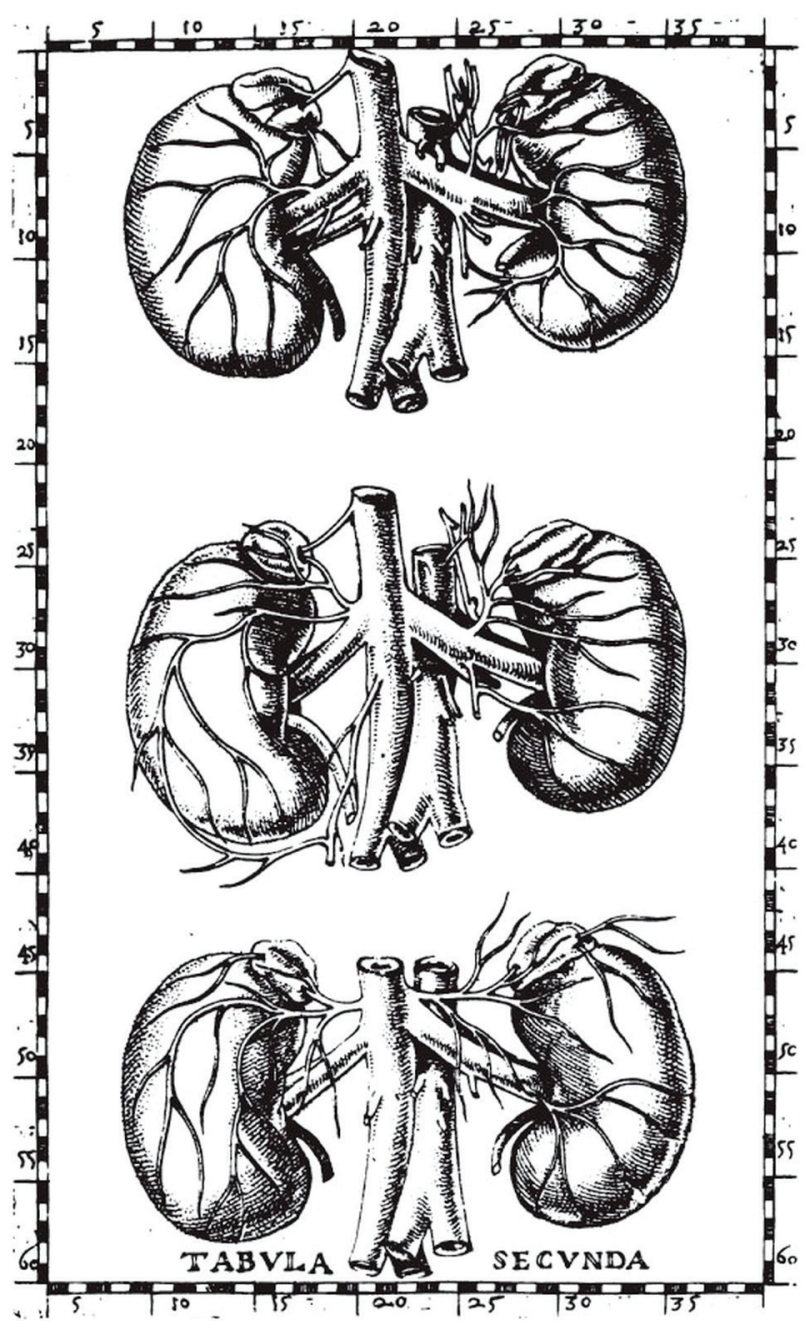

Figure 1. The first depiction of the adrenal glands available by Eustachius in 1552. (Reproduction from: Eustachi B, Lancisi GM. Tabulae anatomicae clarissimi viri Bartholomaei Eustachii quas è tenebris tandem vindicatas: Edition Medicina Rara; 1714. In public domain).
Eustachi quas a tenebris tandem vindicatas" (Anatomical Illustrations of Bartholomeo Eustachio rescued from obscurity) in 1714.

Eustachius' original description of the adrenals provided a new field for argument with his contemporaries over the ensuing years. Arcangelo Piccolomini (1562-1605) in his treatise ${ }^{8}$ vented bitter criticism of Eustachius' findings, reporting that the adrenal glands do not deserve special attention, as they represent rare renal excrescences, caused in a way similar to that causing supernumerary digits: ${ }^{6,7}$ The fact that the glands were rarely identified was underlined by André Du Laurens, physician to Henry IV of France, who in 1640 wrote: "Eustachius claims to find a gland above the kidneys. Sometimes we saw that too; often, however, we stated that there was no such gland". ${ }^{6}$

In 1627, Casserius, a prominent anatomist of Padua, validated Eustachius' discovery and provided illustrations of the adrenal glands, which he termed corpuscula reni incumbentia sive renes succenturiati (renal corpuscles lying on or above the kidney). ${ }^{9}$ Casserius' depiction (Figure 2) was the first to appear, as Eustachius' plates were not published until two centuries after being engraved. His work, however, did not receive the attention it deserved. Marcus Aurelius Severinus (1580-1658) is thought to have been the first to mention a relation between the left adrenal gland and epididymis through an excretory duct. This discovery, suggestive of an "adrenogonadal relationship", was largely overlooked and attributed to Antonio Maria Valsalva (1666-1723) in $1719 .{ }^{6}$

The name, suprarenal gland was introduced by Riolan the Younger in $1655^{6}$ and the "modern" terms medulla and cortex were introduced in 1836 by Nagel. ${ }^{10}$ By the early $18^{\text {th }}$ century, medicine had over 20 theories seeking to explain the function and physiology of the adrenal glands, whose presence was by this time well-established. A comprehensive overview of all these theories is beyond the scope of this study. Casper Bartholin, who considered the adrenals to be hollow organs filled with black bile, called them capsulae atrabiliarae, while an important milestone was reached in 1656 by Thomas Wharton. Wharton was the first to associate the adrenal glands with the nervous system, suggesting a possible role for them in transferring substances from the nerves to the 


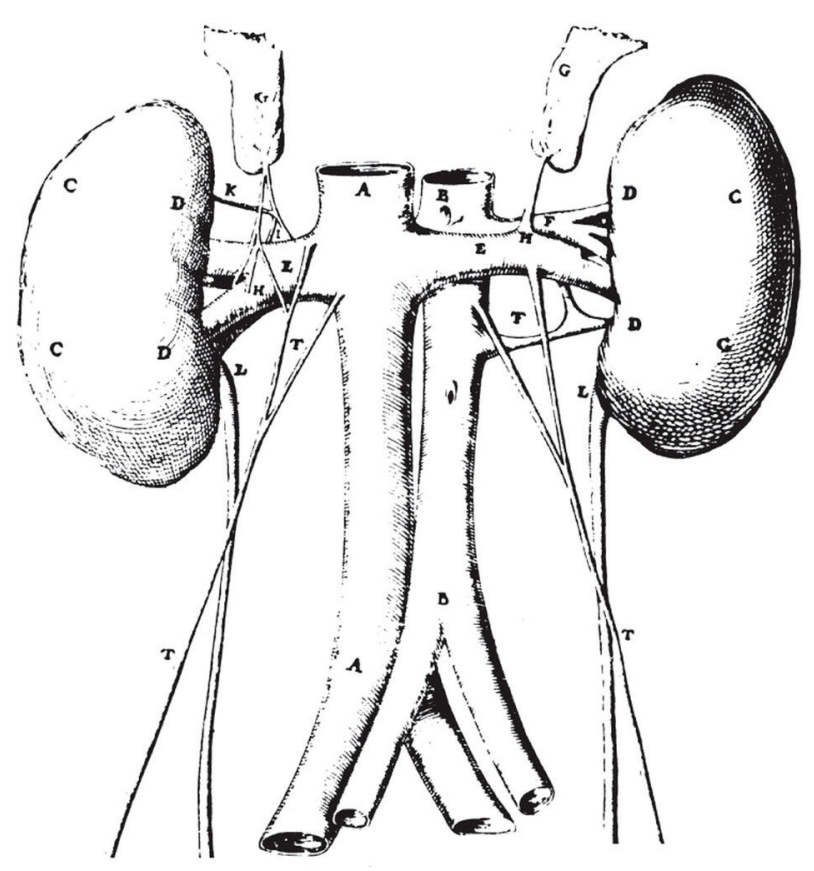

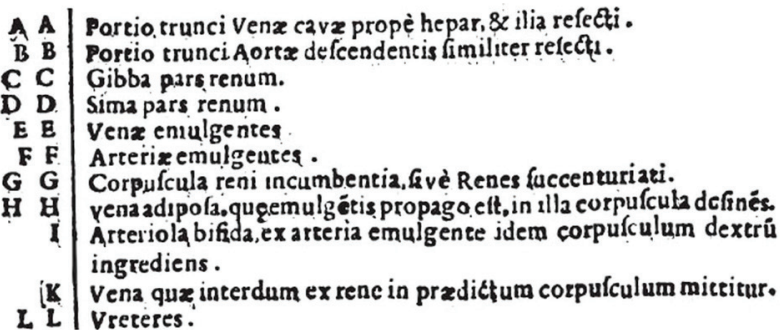

Figure 2. The first depiction of the adrenal glands appeared by Cessarius in 1627. (Reproduction from: Cessarius J. Tabulae anatomicae. Venice: Deuchinus; 1627. In public domain).

circulation. ${ }^{6}$ His idea was affirmed 200 years later when Kölliker provided the first accurate description of the microscopic anatomy of the adrenal gland in 1852. ${ }^{11}$ In 1716, the Academy of Sciences of Bordeaux held a competition offering a prize for an answer to the question "What is the function of the suprarenal glands?" The then 29-year-old French philosopher Montesquieu was asked to judge the competition. However, finding no contestant convincing enough to be awarded the prize, ${ }^{12}$ he expressed the hope that the problem would someday be solved. ${ }^{13}$ In 1805 , Cuvier established that the adrenals were solid structures ${ }^{6}$ and in 1894 George Oliver and Edward Albert Schäfer were the first to demonstrate a hormonal effect by establishing a relation between adrenal medulla and blood pressure. Concluding their findings in a treatise published in 1895, they clarify "that one of the main functions, if not the main function, of the suprarenal capsules is to produce a material which is added in some way or another to the blood". ${ }^{14}$

In 1855, Thomas Addison, in his final publication before his death titled "On the constitutional and local effects of disease of the 'suprarenal capsules" , reported eleven patients with various symptoms, as "anaemia, general langour and debility, remarkable feebleness of the heart's action, irritability of the stomach and a peculiar change of colour in the skin, occurring in connexion with a diseased condition of the 'suprarenal capsules"'. Addison states that "the disease is by no means of very rare occurrence". ${ }^{15}$ In 1896, William Osler first used an adrenal extract to treat a 21-year-old girl suffering from Addison disease who died "during the treatment with the suprarenal extract". ${ }^{16}$ Osler, however, kept up his research and in the same year published his experience with 6 addisonian patients, including one who greatly benefited from the use of the extract. ${ }^{17}$ In 1897, John Jacob Abel became to first to isolate an endocrine secretion as a chemically-pure substance, i.e. epinephrine. Some years later Jokichi Takamine and Thomas Bell Aldrich Takamine were the first to independently isolate epinehrine in a crystalline form. ${ }^{6}$ The first description of a successful adrenalectomy was reported in 1890 by Thornton, who one year earlier employed a T-shaped incision to remove a 20-pound adrenal tumor with the left kidney from a 36-year-old woman. The tumor was most probably a malignant adrenocortical carcinoma and the patient died 2 years later from recurrence. ${ }^{18}$ In 1932, Lennox Broster described a unilateral, transpleural, transdiaphragmatic adrenalectomy through a long posterior, intercostal approach for adrenogenital syndrome associated with cortical hyperplasia. ${ }^{19}$ In the same year, Cushing was the first to recognize the role of the adrenal cortex in pituitary baseophilism, describing an endocrine syndrome causing hypercortisolism through excessive secretion by the cortex..$^{20}$ The disease, now referred to as Cushing syndrome, was termed "suprarenal cortical syndrome", a term also sometimes used to describe adrenal virilism. ${ }^{21}$ By this time, the search for potent cortical extracts had reached its peak. The research was primarily led by Edward Calvin Kendall at the Mayo Clinic and Reichstein in Zürich. Their intensive efforts resulted in the isolation of cortisone 
and its essential components in the late $1930 \mathrm{~s}^{22} \mathrm{In}$ 1934, Walters et al at the Mayo Clinic were the first to report ten cases of subtotal adrenalectomy for patients with "suprarenal cortical syndrome", with a mortality rate of 30\% despite using Kendall's potent cortical extracts. ${ }^{23}$ In 1936, Hugh Young of Johns Hopkins reported a posterior approach with the removal of the 12 th rib for simultaneous exposure of both adrenals in Cushing patients. ${ }^{24}$

In 1949, James Priestley at the Mayo Clinic reported his experience in 29 adrenalectomized patients with Cushing syndrome. In the first 20 cases, a preand postoperative replacement therapy with aqueous adrenal cortical extract was employed. The last nine cases were treated with cortisone in place of aqueous adrenal cortical extract. No deaths were observed in the cortisone group, in comparison with the 30\% mortality rate in the aqueous cortical extract group. ${ }^{25}$ These results, supported by larger subsequent studies, established the use of the replacement therapy. In 1886, Felix Fränkel described an 18-year-old woman who died from progressive circulatory failure 9 days after hospital admission with paroxysmal hypertensive crises. ${ }^{26}$ The autopsy revealed bilateral adrenal tumors, which apparently were pheochromocytomas. ${ }^{27}$ Since no signs of Addison's disease, the only known clinical entity of adrenal pathology at the time, were observed, Fränkel attributed the death to severe nephritis, considering the adrenal tumors as latent. Similar adrenal tumors were identified in subsequent years and were termed "paragangliomas", coined by Alezais and Peyron in 1908. ${ }^{28}$ It was not until 1912 that the term pheochromocytoma was used by Ludwig Pick to refer to tumors in the adrenals and at extra-adrenal sites. ${ }^{29}$ The first comprehensive tumor description together with association with symptoms and signs was published 10 years later by Labbé et al..$^{30}$ In 2007, Neumann et al reviewed Fränkel's publication, addressing the hypothesis that the patient had an inherited disorder. The presence of germ-line RET mutations in four living descendants established the clinical and molecular diagnosis of MEN-2 in Fränkel's original description. ${ }^{31}$

The first surgically treated patient with a pheochromocytoma in 1923 died in shock, the event being regarded as "disproportionate to the severity of the operation". ${ }^{27}$ The first known successful surgical removal of a pheochromocytoma was performed on 25 February 1926 by César Roux (1857-1934) in Lausanne, Switzerland. The patient was a woman suffering from paroxysmal hypertensive crises who had noticed an orange-sized lump under her right costal margin, with an X-ray pattern resembling a liver tumor. The patient underwent surgical exploration and a tumor attached to the right adrenal was found and removed. The postoperative period was uneventful with no recurrence or complications during a follow-up period of 18 months. ${ }^{27}$ The second successful removal of a pheochromocytoma was independently carried out by Charles Mayo 7 months later in Minnesota, USA. Using a flank incision, ${ }^{32}$ Mayo removed a lemonsized tumor, apparently separate from the adrenal of a patient with paroxysmal hypertension. ${ }^{27}$ The tumor, with the appearance of a typical pheochromocytoma, was given several names, such as "retroperitoneal malignant blastoma" and "encapsulated fibrous cellular retroperitoneal malignant neoplasm". The patient was disease-free during the follow-up period and died after 18 years from coronary thrombosis. ${ }^{27}$ The following year, 1927, Mayo had his work published, ${ }^{33}$ one year earlier than Roux, whose case was included in the thesis of Roland von der Mühll, a pathologist working in Lausanne, published in $1928 .^{34}$ Thus, Mayo was primarily credited with the first successful pheochromocytoma removal and Roux is best known for the Roux-en-Y anastomosis, popularized in $1893 .{ }^{35}$ By 1940, about 20 operations for pheochromocytomas had been reported, a number that rose to 151 , with a $26 \%$ mortality rate, by $1951 .{ }^{27}$

The evolution of laparoscopic adrenalectomy serves as the first-line of therapy for the management of most functional and non-functional adrenal tumors. ${ }^{36}$ Gagner et al were the first to report three cases of laparoscopic adrenalectomy in the lateral decubitus position in two patients with Cushing syndrome and a 60 -year-old man with pheochromocytoma in $1992 .{ }^{37}$ This technique gained widespread acceptance, being considered the most popular technique for the past decade. ${ }^{38}$ In the same year, Higashihara et al published in Japanese a case of laparoscopic adrenalectomy for primary aldosteronism utilizing a subcutaneous steel traction method to reduce $\mathrm{CO}_{2}$ insufflation pressure..$^{39}$ The following year, the authors summed up their experience with this method reporting three 
patients with primary aldosteronism who underwent successful laparoscopic adrenalectomy. ${ }^{40}$ Gagner recognizes two presentations of their findings at the American Association of Endocrine Surgery ${ }^{41}$ and the American Surgical Association ${ }^{42}$ as landmarks "that gave a stamp of approval for this technique", stating that "the work of a pioneer is not only to describe the technique but also to convince the world surgical community that these changes are significant". ${ }^{38}$ In the latter of the two works, the authors reported 97 laparoscopic adrenalectomies with no mortality, no recurrence of hormonal excess and a conversion rate of $3 \%$, suggesting that the open procedure should be reserved for cases of invasive adrenal carcinoma and malignant pheochromocytoma. ${ }^{42}$ Mercan et al should be credited for introducing the endoscopic retroperitoneal approach in clinical practice, recording successful resection in eight patients with benign adrenal lesions in $1995 .{ }^{43}$ Both these innovative surgical techniques simplified the procedure, resulting in less postoperative morbidity and a shorter recovery period, this becoming the new gold standard in adrenal surgery.

\section{REFERENCES}

1. Buckley TA 1851 The Iliad. Bohn; pp, 389-390.

2. Wenham GJ 1979 The book of Leviticus. Wm. B. Eerdmans Publishing, Michigan; pp, 73.

3. Kühn C 1821 Claudii Galeni opera omnia. Vol 2, Knobloch, Leipzig; pp, 779.

4. Goss CM 1961 On anatomy of veins and arteries by Galen of Pergamos. The Anatomical Record 141: 355366.

5. Eustachius B 1564 Opuscula anatomica de renum structura, efficio et adminstratione, Vicentius Luchinus, Venice.

6. Carmichael SW, 1989 The history of the adrenal medulla. Rev Neurosci 2: 83-100.

7. Lenard A, 1951 The History of Research on the Adrenals 1563-1900. J Hist Med Allied Sci 6: 496-505.

8. Piccolomini A 1586 Anatomicae praelectiones Archangeli Piccolhomini...: explicantes mirificam corporis humani fabricam, et quae anima vires, quibus corporis partibus, tanquàm instrumentis, ad suas obeundas actiones utantur, sicuti tota anima, toto corpore. Romae, Ex Typographia Batholomaei Bonfadini.

9. Casserius J 1627 Tabulae anatomicae. Deuchinus, Venice.

10. Nagel N, 1836 Über die Struktur der Nebennieren. Arch Anat Phys Wiss Med: 365-383.

11. Kölliker A 1854 Manual of human histology. Vol 2.
Sydenham society, London; pp, 218.

12. Biedl A 1913 The internal secretory organs: their physiology and pathology. W. Wood, New York pp, 124.

13. Calliau JM 1819 Notice sur les glandes surrénales, suivie d'un discours prononcé sur le même sujet de Montesquieu en 1718. Ann. clin. d. 1. S. d.med. de Montpellier.

14. Oliver G, Schäfer EA, 1895 The physiological effects of extracts of the suprarenal capsules. J Physiol 18: 230-276.

15. Wilson E 1867 On Diseases of the Skin; a System of Cutaneous Medicine. John Churchill \& Sons, London.

16. Osler W, 1896 Case of Addison's disease: death during treatment with the suprarenal extract. Bull Johns Hopkins Hosp 7: 208-209.

17. Osler W, 1896 On six cases of Addison's disease: with the report of a case greatly benefited by the use of the suprarenal extract. Internat Med Mag 5: 3-11.

18. Thornton J, 1890 Abdominal nephrectomy for large sarcoma of the left suprarenal capsule: recovery. Trans Clin Soc Lond 23: 150-153.

19. Broster L, Hill HG, Greenfield J, 1932 The adrenogenital syndrome associated with cortical hyperplasia; the results of unilateral adrenalectomy. Br J Surg 19: 557-570.

20. Cushing H, 1932 The basophil adenomas of the pituitary body and their clinical manifestations. Pituitary Basophilism. Bull Johns Hopkins Hosp 50: 137-195.

21. Welbourn RB 1990 The adrenals. In: Welbourn RB The history of endocrine surgery, Greenwood Publishing Group, New York.

22. Welbourn RB, 1996 Highlights from endocrine surgical history. World J Surg 20: 603-612.

23. Walters W, Wilder RM, Kepler EJ, 1934 The suprarenal cortical syndrome with presentation of ten cases. Ann Surg 100: 670.

24. Young HH, 1936 A technique for simultaneous exposure and operation on the adrenals. Surg Gynecol Obstet 63: 179-188.

25. Priestley JT, Sprague RG, Walters W, Salassa RM, 1951 Subtotal adrenalectomy for Cushing's syndrome: a preliminary report of 29 cases. Ann Surg 134: 464472.

26. Fränkel F, 1886 Ein Fall von doppelseitigem, völlig latent verlaufenen Nebennierentumor und gleichzeitiger Nephritis mit Veränderungen am Circulationsapparat und Retinitis. Virchows Arch 103: 244-263.

27 . Welbourn R, 1987 Early surgical history of phaeochromocytoma. Br J Surg 74: 594-596.

28. Alezais H, Peyron A, 1908 Un groupe nouveau de tumeurs épithéliales: les paraganglions. Compte Rend Soc Biol (Paris) 65: 745-747.

29. Pick L, 1912 Das Ganglioma embryonale sympathicum (Sympathoma embryonale). Berl Klin Wschr 49: 16-22.

30. Labbé M, Tinel J, Doumer A, 1922 Crises solaires et hypertension paroxystique en rapport avec une tumeur 
surrénale. Bull Soc Med Hop 46: 982-990.

31. Neumann HP, Vortmeyer A, Schmidt D, et al, 2007 Evidence of MEN-2 in the original description of classic pheochromocytoma. N Engl J Med 357: 1311-1315.

32. Harris D, Wheeler M 2005 History of Adrenal Surgery. In: Linos D, van Heerden J, eds. Adrenal Glands, Springer, Heidelberg; pp, 1-6.

33. Mayo CH, 1927 Paroxysmal hypertension with tumor of retroperitoneal nerve: report of case. JAMA 89: 1047-1050.

34. von der Mühll R 1928 Contribution à l'étude des paragangliomes de la surrénale, G. Vaney-Burnier SA.

35. Roux C, 1893 Chirurgie gastrointestinale. Revue de Chirurgie 13: 402-403.

36. Lal G, Duh QY, 2003 Laparoscopic adrenalectomy-indications and technique. Surg Oncol 12: 105-123.

37. Gagner M, Lacroix A, Bolte E, 1992 Laparoscopic adrenalectomy in Cushing's syndrome and pheochro- mocytoma. N Engl J Med 327: 1033.

38. Gagner M, 2003 Pioneers in laparoscopic solid organ surgery. Surg Endosc 17: 1853-1854.

39. Higashihara E, Tanaka Y, Horie S, et al, 1992 [A case report of laparoscopic adrenalectomy]. Nihon Hinyokika Gakkai Zasshi 83: 1130-1133.

40. Higashihara E, Tanaka Y, Horie S, et al, 1993 Laparoscopic adrenalectomy: the initial 3 cases. J Urol 149: 973-976.

41. Gagner M, Lacroix A, Prinz RA, et al, 1993 Early experience with laparoscopic approach for adrenalectomy. Surgery 114: 1120-1125.

42. Gagner M, Pomp A, Heniford BT, Pharand D, Lacroix A, 1997 Laparoscopic adrenalectomy: lessons learned from 100 consecutive procedures. Ann Surg 226: 238.

43. Mercan S, Seven R, Ozarmagan S, Tezelman S, 1995 Endoscopic retroperitoneal adrenalectomy. Surgery 118: 1071-1076. 